\title{
Partial Purification and Study of Osteocalcin from Blood of Human and Rats
}

\author{
Thikra A. Allwsh \\ Liqa'a S. Abdulla \\ Department of Chemistry/ College of Science/ University of Mosul
}

(Received 26/2/2018; Accepted 3/5/2018)

\begin{abstract}
This study is concerned with attempts to isolate and purify osteocalcin from healthy human blood plasma and healthy rats blood serum using different biochemical techniques. This included precipitation by cold acetone and gel filtration chromatography. It was found that only the second peak (peak B) from human and rats had concentration of osteocalcin, and showed that fold of purification of isolated osteocalcin 57 and 43 for human and rats respectively.

The results obtained from electrophoresis showed that one single band for isolated osteocalcin (peak B) from human and rats, and from high performance liquid chromatography showed that there was a good identical in retention time between the standard and isolated osteocalcin (peak B) from human and rats. The comparative molecular weight of partially purified osteocalcin from human plasma and rats serum was $(6011.73 \pm 400 \mathrm{Da})$ and $(5248.07 \pm 400 \mathrm{Da})$ respectively using gel filtration chromatography, and $(5807.64 \mathrm{Da})$ and $(4786.30 \mathrm{Da})$ respectively using electrophoresis technique.
\end{abstract}

Keywords: osteocalcin, purification, human, rats.

\section{تقفية جزئية ورلمة الاوستيوكالسنمن م الانسلن والجرذل}

\section{الملغص}

تضمن البحث محاولة عزل وتقية الأوستيوكللين من بلازما همشخص سليم ومصل م جرذان سليمة بلستعمل

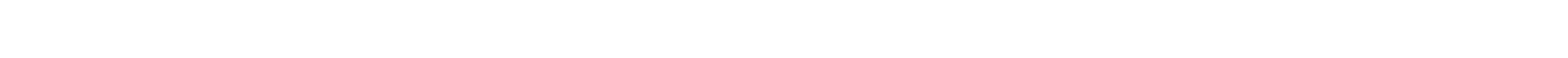

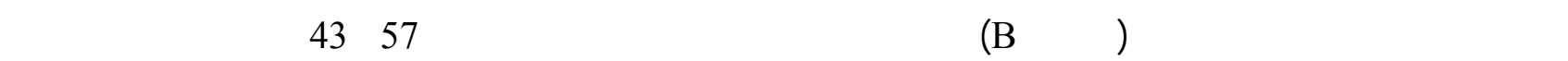
الانسلن والجرذان على التوالمي. بينت النتائج ظهور حزمة مفررة ولحة بلستعمل الهجرة الكهربيائية للأوستيوكللسن (الحزمة B) المعزولة من الإنسان والجرذان، وأن هنك ظابقاَ في وتت الاحتبلس بلستعمل كروماتوغرافيا للسالَ عالي الأداء للأوستيوكللسين القيلسي والأوستيوكللسن (الحزمة B) المعزولة من الإنسان والجرذان، وقد وجد ان الوزن الجزيئي القريبي للأوستيوكللسن المعزول جزئياً من بلازما هم الانسلن ومصل هم الجرذان، هو (400 ـ بلستعمل كروماتوغرافيا الترشيح الهلامي و(5807.64 دالتون) و(4786.30 دالتون) على التوالي بلستعمل نقنية الهجرة الكهربائية.

الكاملت الدالة: الأوستيوكللسن، تقية، لٕنسل، جرذان.

INTRODUCTION

Osteocalcin is one of several non-collagenous proteins contained in bone. Also known in the biomedical literature as BGP or "Bone Gla protein,". Osteocalcin was discovered in the 1970s during a search for the source of the calcium-binding vitamin-K dependent amino acid, $\gamma$ - 
carboxyglutamic acid (Hauschka et al., 1975; Price et al., 1976). After the discovery of osteocalcin in the bone, it was also detected in blood (Price and Nishimoto, 1980). Also it has been isolated from human bone (Poser et al., 1980), and from numerous mammalian rat, mouse, and pig bone (Ivaska, 2005).

Osteocalcin is a low molecular weight protein (5200-5900 daltons) with 46-50 amino-acid residues per molecule, which contains 2 or 3 (Depending on species) residues of Gla per molecule, and it is synthesized in bone by osteoblasts, and after production, some osteocalcin is incorporated into the bone matrix and some is delivered to the circulation (Ferron and Lacombe, 2014; Zoch et al., 2016).

A connection between the skeleton and glucose metabolism is an emerging area of intense scientific scrutiny, so studies have indicated that the osteoblast-derived protein, osteocalcin, regulates energy metabolism, providing a link between these 2 seemingly unrelated systems (Columbia news, 2007, Fattore et al., 2015).Osteocalcin is a bone matrix protein that has been associated with several hormonal actions on energy and glucose metabolism, so animal and experimental models have shown that osteocalcin is released into the blood stream and exerts biological effects on pancreatic beta cells and adipose tissue (Mizokami et al., 2017). Under carboxylated osteocalcin is the hormonally active isoform and stimulates insulin secretion and enhances insulin sensitivity in adipose tissue and muscle. Insulin, in turn, act on bone tissue, modulating the osteocalcin secretion, in a positive feed forward mechanism that places the skeleton as a true endocrine organ (Liu et al., 2016). Recently a relation has been found between osteocalcin, adiponection, and obestatin with diabetes mellitus (Allwsh and Mohammad, 2013; Kanazawa, 2015).

Aim of the research: Attempts to partial purify of osteocalcin from human plasma and rats serum, and to compare between them, since there are few previous studied in Iraq about osteocalcin.

\section{Samples}

\section{MATERIALS AND METHODS}

a human fresh plasma ( $45 \mathrm{~mL})$ was obtained from one healthy male person age (35 years), with assistance of Blood Bank in Mosul city, and male albino rats serum $(25 \mathrm{~mL})$ was separated by centrifugation from blood of male albino rats (13 \pm 1 week old) from animal house, college of veterinary medicine, university of Mosul.

\section{The methods used in the purification of osteocalcin: I-Organic solvent precipitation}

Proteinous materials were precipitated by using acetone (Robyt and White, 1987; Allwsh and Mohammad, 2014). Gradual addition $(60: 40 \mathrm{v} / \mathrm{v})$ cold acetone to plasma with slow stirring at $4^{\circ} \mathrm{C}$ for $60 \mathrm{~min}$. The mixture was left in a refrigerator for $24 \mathrm{~h}$ and the precipitated protein was isolated by centrifugation for 30 minutes $(12000 \mathrm{~g})$ at a refrigerated centrifuge. Protein and osteocalcin concentration were estimated after dissolving the precipitate in a lowest volume of distilled water. Then the solution of proteinous precipitate was kept in a tight sample tube for further step.

\section{II-Gel filtration chromatography}

Packing of the column: It has a dimension of $(2 \times 100 \mathrm{~cm})$ which contained a gel sephadex G-50. Proteinous precipitates solutions which were prepared in section (I) were applied to this column.

The comparative molecular weight of proteinous peak (B), isolated from human plasma and rats serum, which contained osteocalcin concentrations was obtained from its elution volume under the same conditions of known molecular weight in column.

\section{III-Lyophilization technique}

Peaks B (from the column) were dried by freeze drying, this technique was performed in the Department of Chemistry, College of Science, University of Mosul. 


\section{IV-Electrophoresis technique}

A sample from (peak B), isolated from human plasma and rats serum, which contained high osteocalcin concentration was applied on SDS-PAGE (Laemmli, 1970) using slab electro apparatus in the College of Agriculture and Forestry, University of Mosul.

\section{V-High performance liquid chromatography (HPLC)}

A sample from (peak B), isolated from human plasma and rats serum, which contained osteocalcin concentration, and osteocalcin standard (Epitope Diagnostics, Inc, USA) were applied on C18 RP-HPLC (Agilent 1200 series, USA) (Hosoda et al., 1996). This analysis was performed in the state company for drug industries and medical appliances in Nineveh.

\section{VI-Osteocalcin assay}

Osteocalcin concentration was determined by enzyme linked immunosorbent assay (ELISA) technique (Nagasue et al., 2003) using Epitope Diagnostics, Inc kit (USA). This analysis was performed in the immunity laboratory in Al-Salam hospital in Mosul city by using (BIO-TEK INSTRUMENTS, INC), USA.

\section{VII-Determination of protein concentration}

Protein was determined by the method of modified lowry (Schacterle and Pollack, 1973). Bovine serum albumin was used as a standard protein.

\section{RESULTS AND DISCUSSION \\ Purification of osteocalcin from human plasma and rats serum - Organic solvent precipitation}

The precipitate solution which was obtained by cold acetone from human plasma was with high concentration of osteocalcin $(23.77 \mathrm{ng} / \mathrm{ml})$ compared with plasma $(16.55 \mathrm{ng} / \mathrm{ml})$, while the filtrate did not obtain any concentration of osteocalcin hormone. So, the filtrate was neglected. The precipitate solution which was obtained by cold acetone from rats serum was with high concentration of osteocalcin $(2.1 \mathrm{ng} / \mathrm{ml})$ compared with plasma $(1.33 \mathrm{ng} / \mathrm{ml})$, while the filtrate did not obtain any concentration of osteocalcin hormone. So, the filtrate was neglected.

\section{- Gel filtration chromatography}

This technique was applied to separate the proteinous materials, which were obtained by acetone precipitation method from human plasma and rats serum. The results of elution of isolated osteocalcin from human and rats shown in Fig. (1) and (2) respectively and indicated that there were two peaks (A \& B). The elution volume of peak A \& B were $(89.47 \mathrm{ml}),(223 \mathrm{ml})$ respectively for isolated osteocalcin from human, and elution volume of peak A \& B were $(93.0 \mathrm{ml}),(230 \mathrm{ml})$ respectively for isolated osteocalcin from rats. Only peak (B) from human plasma and rats serum was obtained with high concentration of osteocalcin.

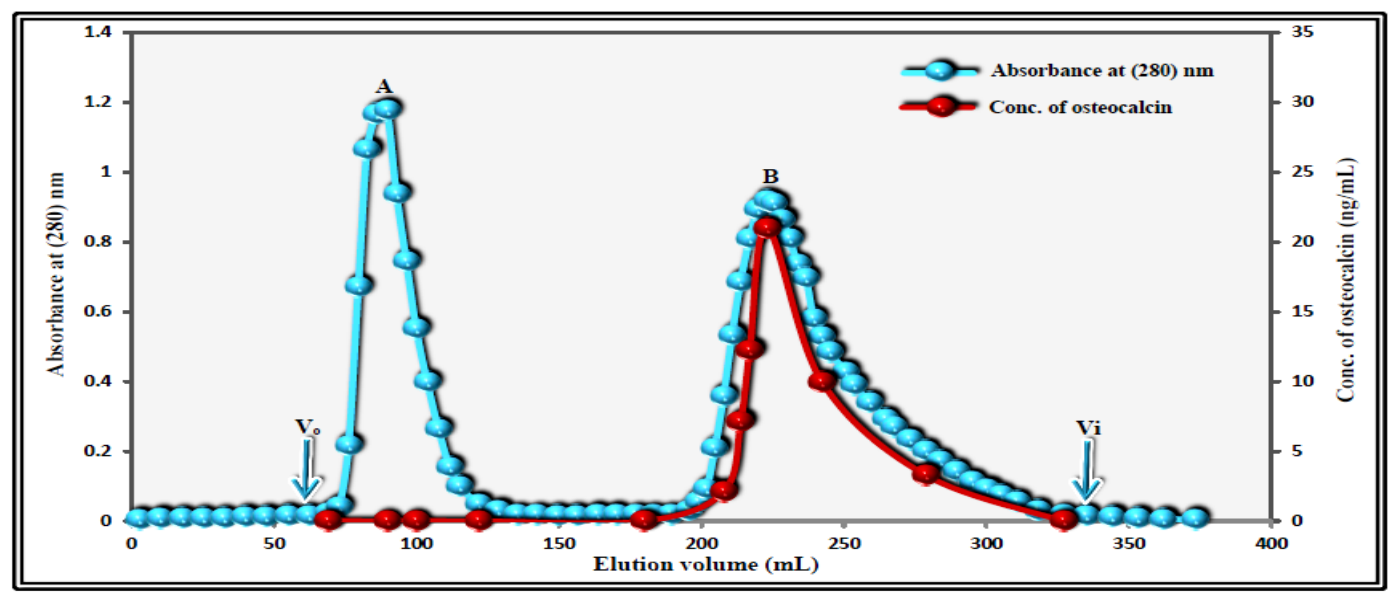

Fig. 1: Elution profile of proteinous precipitate solution obtained from acetone precipitation of human plasma on Sephadex G-50.The dimensions of the column are $(2 \times 100 \mathrm{~cm})$. 


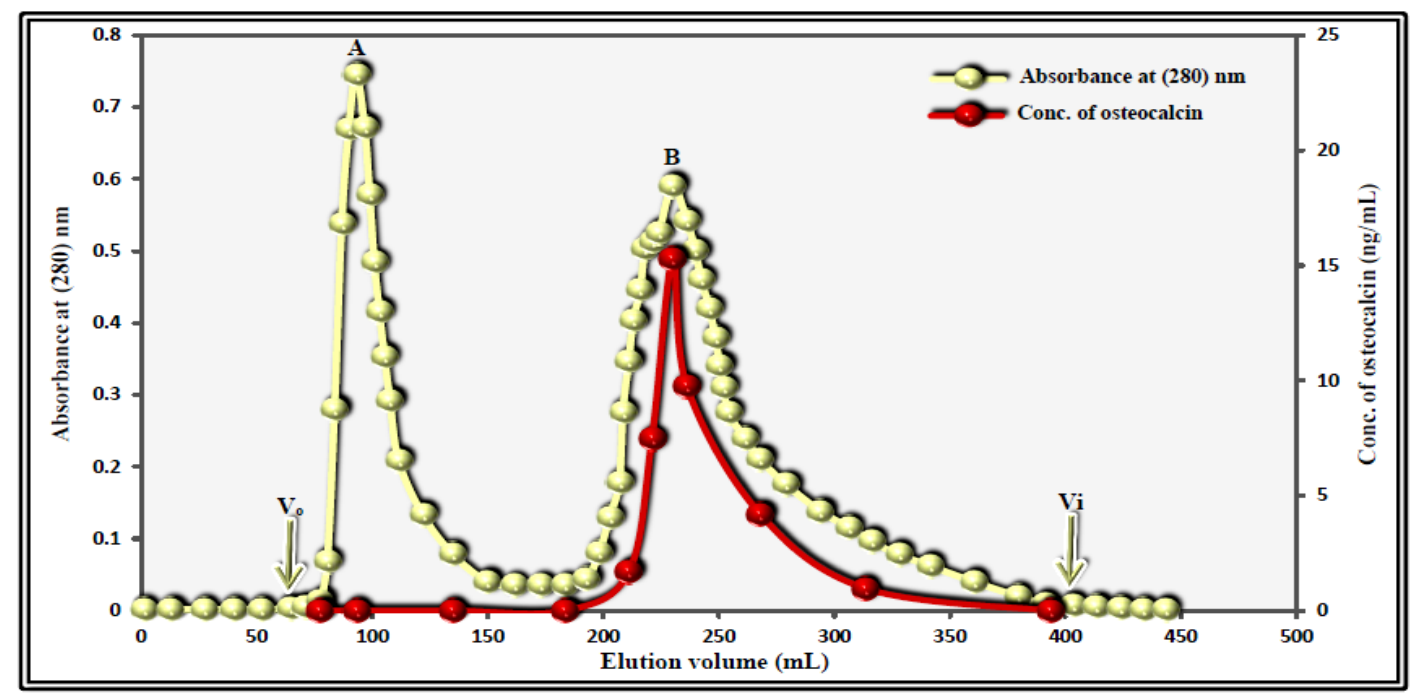

Fig. 2: Elution profile of proteinous precipitate solution obtained from acetone precipitation of rats serum on Sephadex G-50.The dimensions of the column are $(2 \times 100 \mathrm{~cm})$.

The results of all purification steps for osteocalcin from human plasma and rats serum were listed in Table (1) and Table (2) respectively:

Table 1: Partial purification of osteocalcin from human plasma

\begin{tabular}{|c|c|c|c|c|c|c|}
\hline $\begin{array}{c}\text { Purification } \\
\text { steps }\end{array}$ & $\begin{array}{c}\text { Volume } \\
\text { (ml) }\end{array}$ & $\begin{array}{c}\text { Total } \\
\text { protein } \\
\text { (mg) }\end{array}$ & $\begin{array}{c}\text { Total conc. } \\
\text { of } \\
\text { osteocalcin } \\
\text { (ng) }\end{array}$ & $\begin{array}{c}\text { Total specific } \\
\text { conc. of } \\
\text { osteocalcin } \\
\text { (ng/ mg) }\end{array}$ & $\begin{array}{c}\text { Recovery } \\
\text { \% }\end{array}$ & $\begin{array}{c}\text { Fold of } \\
\text { purification }\end{array}$ \\
\hline Plasma & 45 & 319.5 & 744.75 & 2.33 & 100 & 1 \\
\hline $\begin{array}{c}\text { Proteinous precipitate } \\
\text { solution by cold acetone }\end{array}$ & 30 & 143.4 & 713.1 & 4.97 & 95.75 & 2 \\
\hline $\begin{array}{c}\text { Gel filtration/ Sephadex } \\
\text { G-50 (peak B) }\end{array}$ & 10 & 4.7 & 620 & 131.91 & 83.24 & 57 \\
\hline
\end{tabular}

The results in Table (1) showed that the concentration of osteocalcin was increased from $(16.55 \mathrm{ng} / \mathrm{ml})$ in plasma to $(23.77 \mathrm{ng} / \mathrm{ml})$ for proteinous precipitate solution concentration of osteocalcin, and to $(62 \mathrm{ng} / \mathrm{ml})$ for peak B concentration of osteocalcin used in gel filtration by using (Sephadex G-50). While the concentration of protein was decreased.

Table 2: Partial purification of osteocalcin from rats serum

\begin{tabular}{|c|c|c|c|c|c|c|}
\hline $\begin{array}{c}\text { Purification } \\
\text { steps }\end{array}$ & $\begin{array}{c}\text { Volume } \\
\text { (ml) }\end{array}$ & $\begin{array}{c}\text { Total } \\
\text { protein } \\
\text { (mg) }\end{array}$ & $\begin{array}{c}\text { Total conc. of } \\
\text { osteocalcin } \\
\text { (ng) }\end{array}$ & $\begin{array}{c}\text { Total specific } \\
\text { conc. of } \\
\text { osteocalcin } \\
\text { (ng/ mg) }\end{array}$ & $\begin{array}{c}\text { Recovery } \\
\text { \% }\end{array}$ & $\begin{array}{c}\text { Fold of } \\
\text { purification }\end{array}$ \\
\hline Serum & 25 & 158.5 & 33.25 & 0.21 & 100 & 1 \\
\hline $\begin{array}{c}\text { Proteinous precipitate } \\
\text { solution by cold acetone }\end{array}$ & 14 & 60.34 & 29.4 & 0.49 & 88.42 & 2 \\
\hline $\begin{array}{c}\text { Gel filtration/Sephadex } \\
\text { G-50 (peak B) }\end{array}$ & 5 & 2.65 & 23.85 & 9 & 71.73 & 43 \\
\hline
\end{tabular}


The results in Table (2) showed that the concentration of osteocalcin was increased from $(1.33 \mathrm{ng} / \mathrm{ml})$ in serum to $(2.1 \mathrm{ng} / \mathrm{ml})$ for proteinous precipitate solution concentration of serum rats, and to $(4.77 \mathrm{ng} / \mathrm{ml})$ for peak $\mathrm{B}$ concentration of osteocalcin used in gel filtration by using (Sephadex G-50). While the concentration of protein was decreased.

To check the purity of isolated osteocalcin (peak B) from human plasma and rats serum, SDSPAGE and RP-HPLC were used as shown below:

\section{1-SDS-poly acrylamide gel electrophoresis}

Osteocalcin (peak B from sephadex G-50) exhibited only one singly band, using SDSelectrophoresis as shown in (Fig. 3). This result was in a highly agreement with previous results published by other investigators (Nishimoto et al., 2003; Oldknow et al., 2015). Who found that osteocalcin was a protein consisted of (49 amino acids) and (46 amino acids) in human and mice respectively.

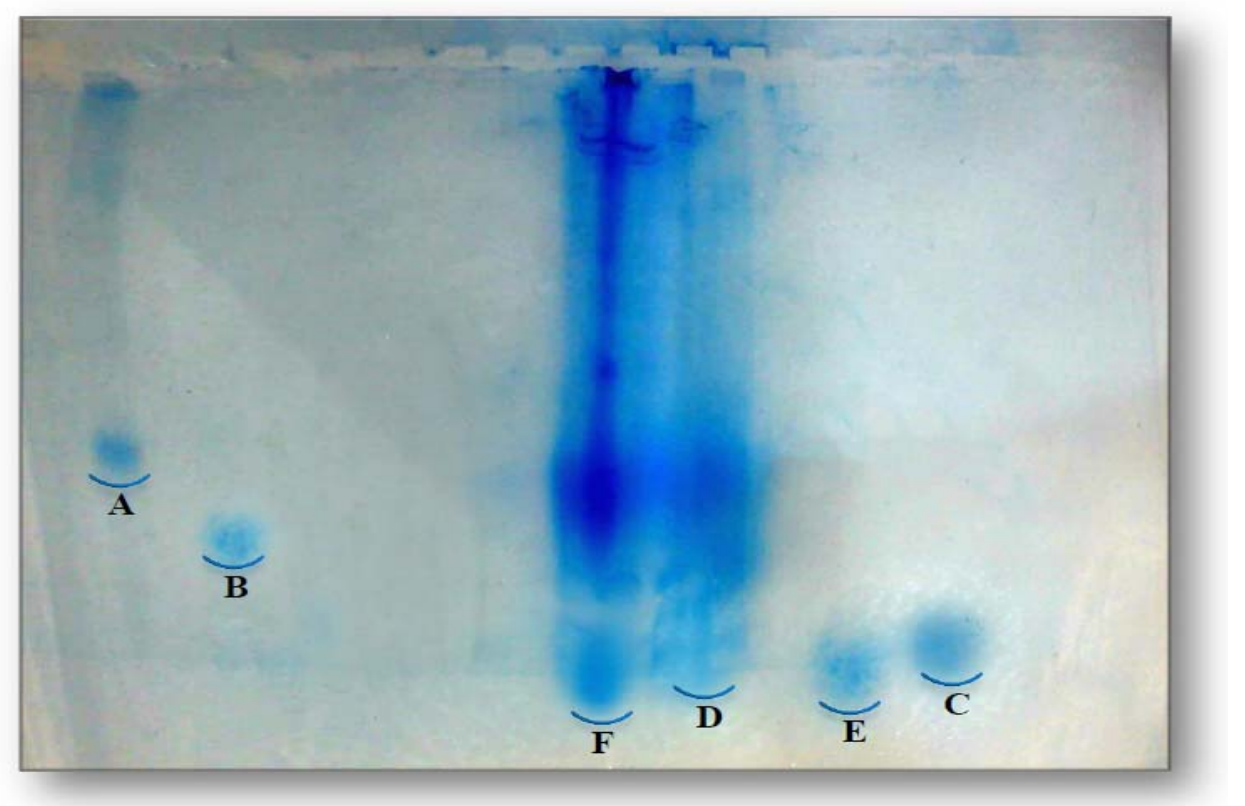

Fig. 3: SDS -polyacrylamide gel electrophoresis of partially purified osteocalcin from human plasma and rats serum and known molecular weight proteins.

Band (A) represent bovine serum albumin(BSA), band (B) prolactin, band (C) isolated osteocalcin (peak B) from human plasma, band (D) insulin without $\beta-\mathrm{ME}$, band (E) isolated osteocalcin (peak B) from rats serum, band $(\mathrm{F})$ insulin with $\beta$-ME.

$\beta$-ME: $\beta$-mercaptoehanol.

\section{2-Reversed phase high performance liquid chromatography}

To determine the purity of osteocalcin (peak B) from all from human plasma and rats serum, the standard solution of osteocalcin was introduced into the column of RP-HPLC apparatus to know the retention time for it under the following conditions (Hosoda et al., 1996):

Flow rate: $1 \mathrm{~mL} / \mathrm{min}$, Temp: At ambient, Wave length: $210 \mathrm{~nm}$, Pressure: $12 \mathrm{MPa}$

The mobile phase was made with two solvents: A and B (Hosoda et al., 1996).

Solvent A: $0.1 \%$ triflouroacetic acid/deionized water. Solvent B: $80 \%$ acetoneitrile, $0.1 \%$ triflouroacetic acid/ deionized water.

The results in (Fig. 4) and Table (3) indicated that there were four peaks for standard osteocalcin, the first, the second, the third, and the fourth (main) peaks were appeared at $(0.068)$ min., (0.826) $\min ,(0.896)$ min, and (1.455) respectively. 
Table 3:The data from RP-HPLC of standared osteocalcin solution and isolated osteocalcin (sample) from human plasma and rats serum

\begin{tabular}{|c|c|c|c|c|c|}
\hline \multirow{2}{*}{ Name of the solution } & peak & Ret. time (min) & width & Area & \%area \\
\hline \multirow{3}{*}{ Standard osteocalcin } & 1 & 0.068 & 0.0704 & 9.02629 & 0.1789 \\
\cline { 2 - 6 } & 2 & 0.826 & 0.0834 & 21.33301 & 0.4228 \\
\cline { 2 - 6 } & 3 & 0.896 & 0.0916 & 19.96387 & 0.3956 \\
\cline { 2 - 6 } & 4 & 1.455 & 0.1950 & $\mathbf{4 9 9 5 . 8 1 0 0 6}$ & 99.0027 \\
\hline \multirow{3}{*}{$\begin{array}{c}\text { Human } \\
\text { osteocalcin }\end{array}$} & 1 & 0.819 & 0.1258 & 20.76495 & 0.6767 \\
\cline { 2 - 6 } & 2 & 1.474 & 0.2774 & $\mathbf{3 0 4 7 . 8 7 7 9 3}$ & 99.3233 \\
\hline \multirow{3}{*}{ Rats osteocalcin } & 1 & 0.810 & 0.1008 & 7.72539 & 0.4276 \\
\cline { 2 - 6 } & 2 & 1.414 & 0.3069 & $\mathbf{1 6 7 8 . 8 2 6 6 6}$ & 92.9325 \\
\cline { 2 - 6 } & 3 & 2.028 & 0.3975 & 119.94979 & 6.6399 \\
\hline
\end{tabular}

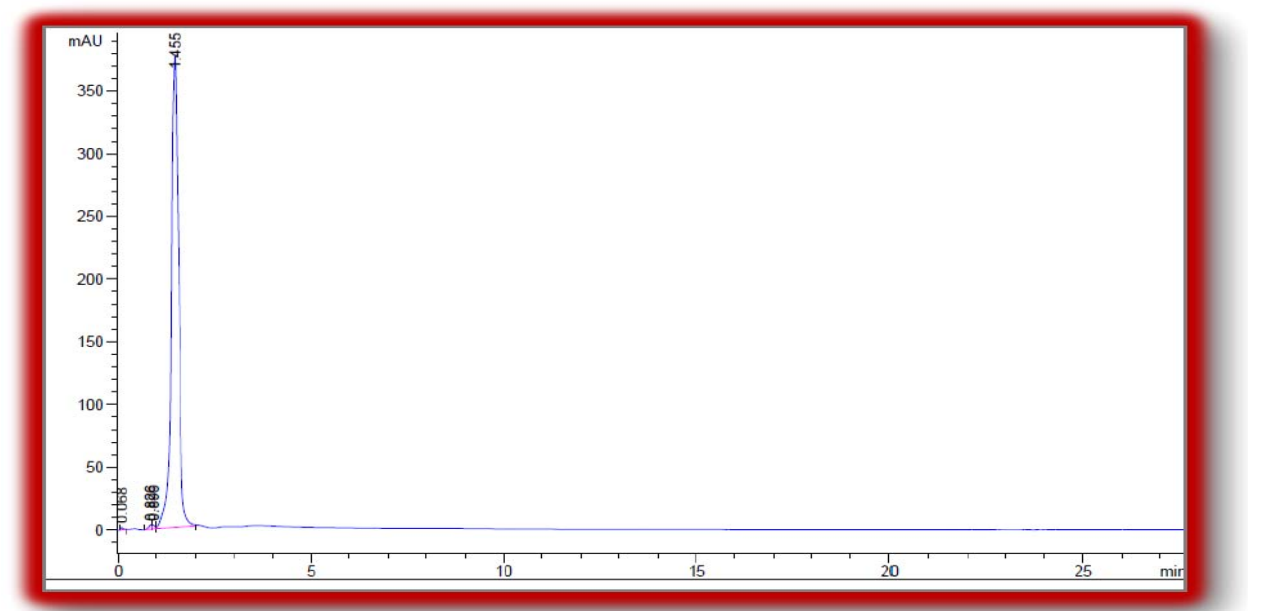

Fig. 4: Chromatogram of osteocalcin standard solution

Also, the results in (Fig. 5) and Table (3) showed that two peaks appeared after introduced the sample of isolated osteocalcin (peak B) from human plasma into the column of RP-HPLC apparatus under the same conditions of standard. The first and the second (main peak) peaks appeared at (0.819), (1.474) min respectively.

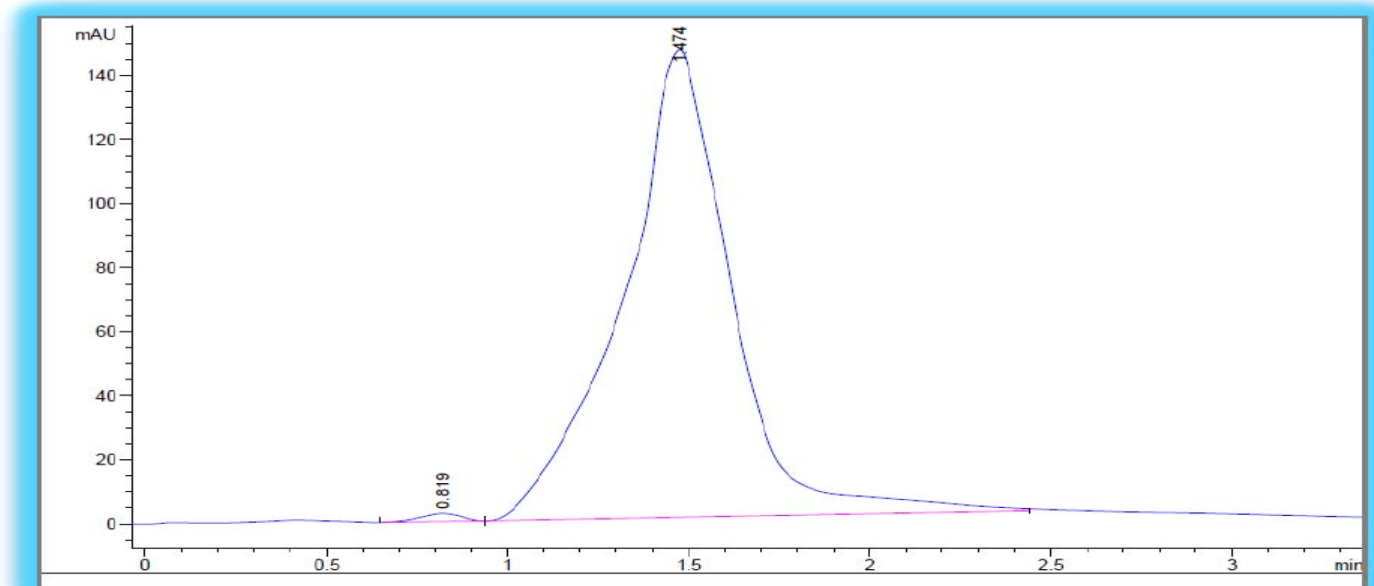

Fig. 5: Chromatogram of isolated osteocalcin solution (peak B) from human plasma by gel filtration (Sephadex G-50).

After comparing the chromatogram of standard with the sample of isolated osteocalcin (peak B) from human plasma it was found that there was a good identical between the retention time of 
standard with sample as shown in (Fig. 4 and 5) and Table (3). So this indicated that isolated osteocalcin (peak B) from human plasma respresent the same properties of osteocalcin standard.

Furthormore, the results in (Fig. 6) and Table (3) showed that three peaks appeared after introduced the sample of isolated osteocalcin (peak B) from rats serum into the column of RPHPLC apparatus under the same conditions of standard. The first, the second (main peak) and the third peaks appeared at (0.810), (1.414) and (2.028) min respectively, these results were in agreement with those obtained by other investigators (Ivaska, 2005), who found that was a main peak of isolated and purified osteocalcin by RP-HPLC from rats osteoblast.

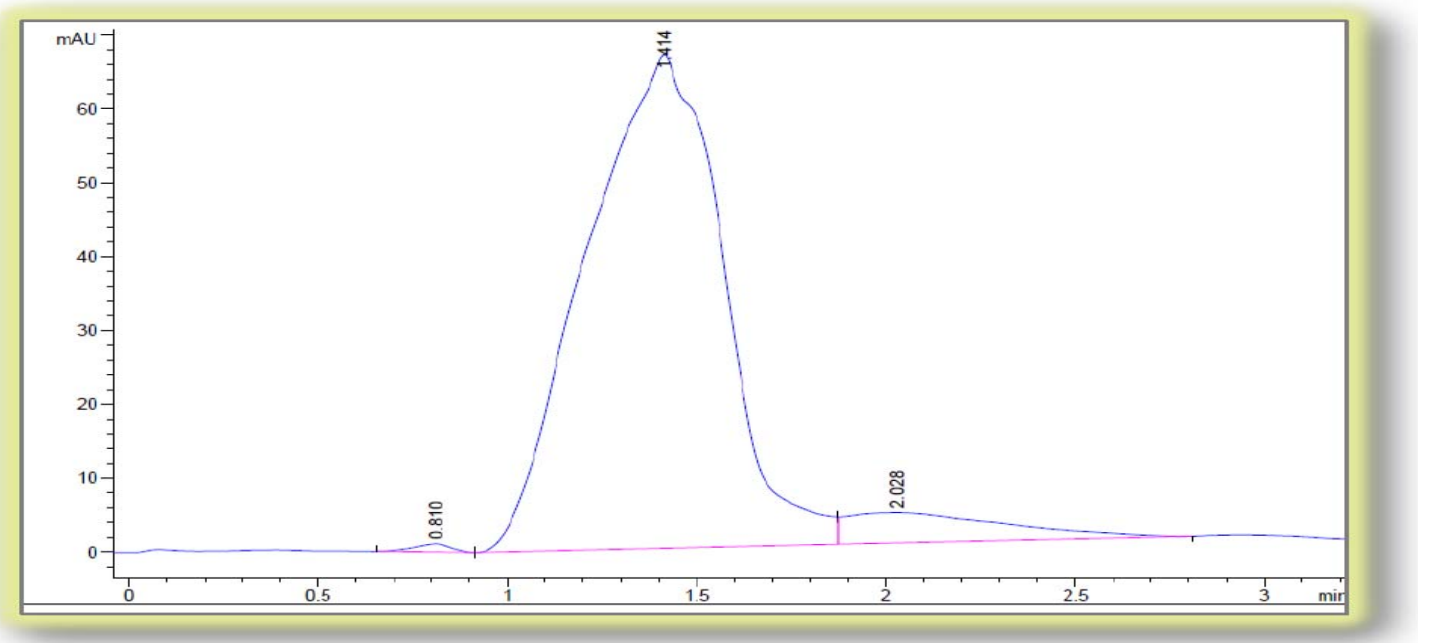

Fig. 6: Chromatogram of isolated osteocalcin solution (peak B) from rats serum by gel filtration (Sephadex G-50).

After comparing the chromatogram of standard with the sample of isolated osteocalcin (peak B) from rats it was found that there was a good identical between the retention time of standard with sample as shown in (Figs. 4 and 6) and Table (3), so this indicated that isolated osteocalcin (peak B) from rats serum respresent the same properties of osteocalcin standard.

On other hand, After comparison the chromatogram of the sample of isolated osteocalcin (peak B) from human plasma with the chromatogram of the sample of isolated osteocalcin (peak B) from rats serum as shown in (Figs. 5 and 6) and Table (3), it was found that there was a good identical between the retention time of them. These results were in agreement with those obtained by other investigators (Ivaska, 2005), who found that there was (76\%) homology between human and rat osteocalcin, also it was found that partial purification osteocalcin (peak B) from human was higher purity than osteocalcin (peak B) from rats by RP-HPLC, these results were in agreement with that results of purification osteocalcin from human and rats by gel filtration (Sephadex G-50) as shown in Table (1) and Table (2) respectively.

\section{Molecular weight determination of osteocalcin}

\section{Molecular weight determination by gel filtration chromatography.}

The comparative molecular weight of peak (B) as a source of purified osteocalcin from human and rats was determined by the elution volum from a sephadex G-50 column calibrated with known molecular weight proteins that as listed in Table (4). Peak (B) of human osteocalcin and peak $(B)$ of rat osteocalcin which approximately equal to $(6011.73 \pm 400)$ Dalton and $(5248.07 \pm$ 400) Dalton as shown in (Fig. 7), these results were approximate to the results with those obtained by other investigators (Poser et al., 1980; Hill et al., 2014), who found that the molecular weight of isolated osteocalcin by gel filtration chromatograph from human bone (5879) Dalton and the molecular weight of isolated osteocalcin (5249) Dalton by mass spectrophotometry from mouse bone. 
Table 4: Elution volumes of known molecular weight materials on sephadex G-50

\begin{tabular}{|c|c|c|}
\hline Materials & Molecular Weight (Dalton) & Elution Volume(mL) \\
\hline Blue dextran & 2000000 & 54.59 \\
\hline Bovine serum albumin & 67000 & 104 \\
\hline Egg albumin & 45000 & 123.5 \\
\hline Prolactin & 24000 & 154.8 \\
\hline Insulin & 5734 & 226 \\
\hline Oxytocin & 1051 & 309 \\
\hline Tryptophan & 204 & 403.47 \\
\hline Peak B of human osteocalcin & 6011.73 & 223 \\
\hline Peak B of rats osteocalcin & 5248.07 & 230 \\
\hline
\end{tabular}

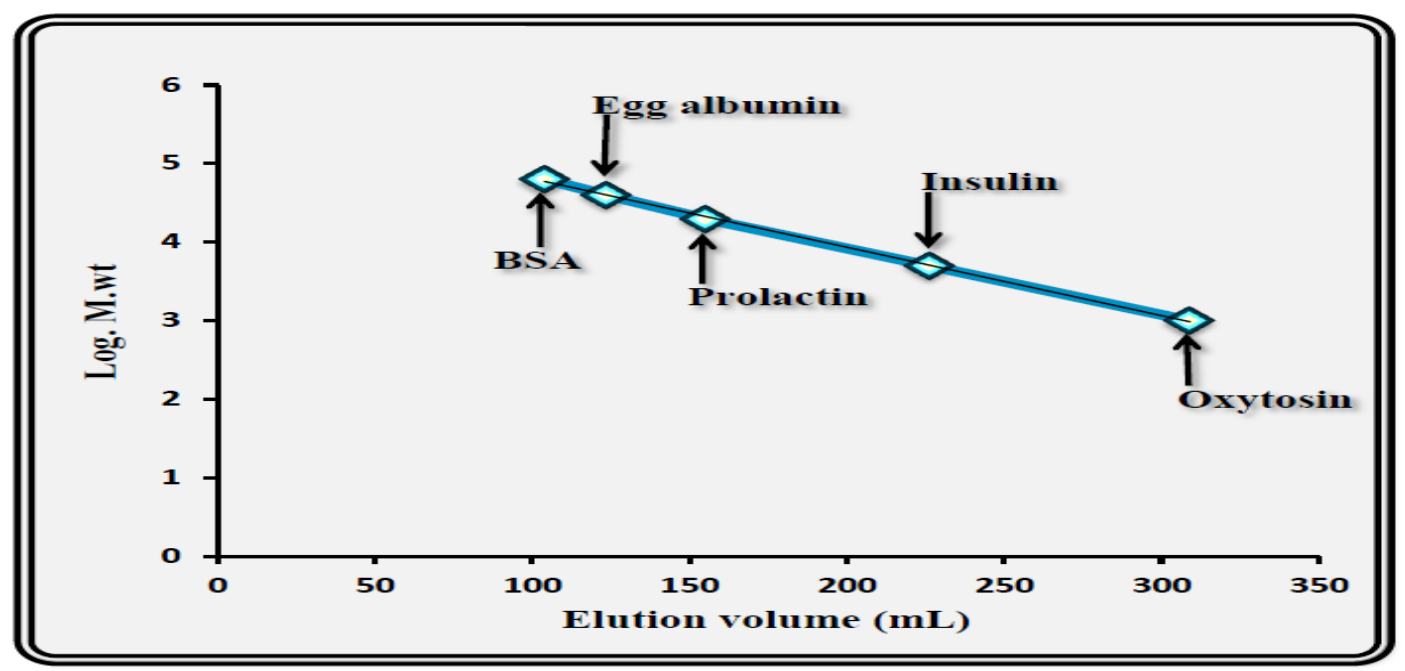

Fig. 7: A plot of the logarithm molecular weight of known proteins verses elution volumes on a Sephadex G-50

\section{Molecular weight determination by SDS-PAGE:}

The molecular weight of peak (B) as a source of purified osteocalcin from human plasma and rats serum was determined, using known molecular weight compounds and found to be in the range of (5807.64) Dalton and (4786.30) Dalton respectively as shown in Table (5) and (Fig. 8), these results were approximate to the results with those obtained by other investigators (Viegas et al., 2002), who found that the molecular weight of isolated osteocalcin by SDS-PAGE from bone of Xenopuslaevis and Sparusaurata, a teleost fish, (5359.79) Dalton and (4950.63) Dalton respectively.

Table 5: Distance of known molecular weight materials on SDS-PAGE

\begin{tabular}{|c|c|c|}
\hline Materials & $\begin{array}{c}\text { Molecular Weight } \\
\text { (Dalton) }\end{array}$ & $\begin{array}{c}\text { Distance } \\
(\mathbf{c m})\end{array}$ \\
\hline BSA & 67000 & 5.7 \\
\hline Prolactin & 24000 & 7.2 \\
\hline Insulin(without $\beta$-M.E) & 5734 & 9 \\
\hline (Insulin $+\beta-M E)$ chain B & 3430 & 9.8 \\
\hline (Insulin $+\beta-M E)$ chain A & 2384 & 10.1 \\
\hline Peak B of human osteocalcin & 5807.64 & 8.8 \\
\hline Peak B of rats osteocalcin & 4786.30 & 9.2 \\
\hline
\end{tabular}


And when we draw the distances of known molecular weight materials obverse their molecular weight, appears straight line and through it, we can determine the approximate molecular weight, as shown in (Fig. 8), as (peak B) of osteocalcin human give one band at $(8.8 \mathrm{~cm})$, while (peak B) of osteocalcin rats give one band at $(9.2 \mathrm{~cm})$.

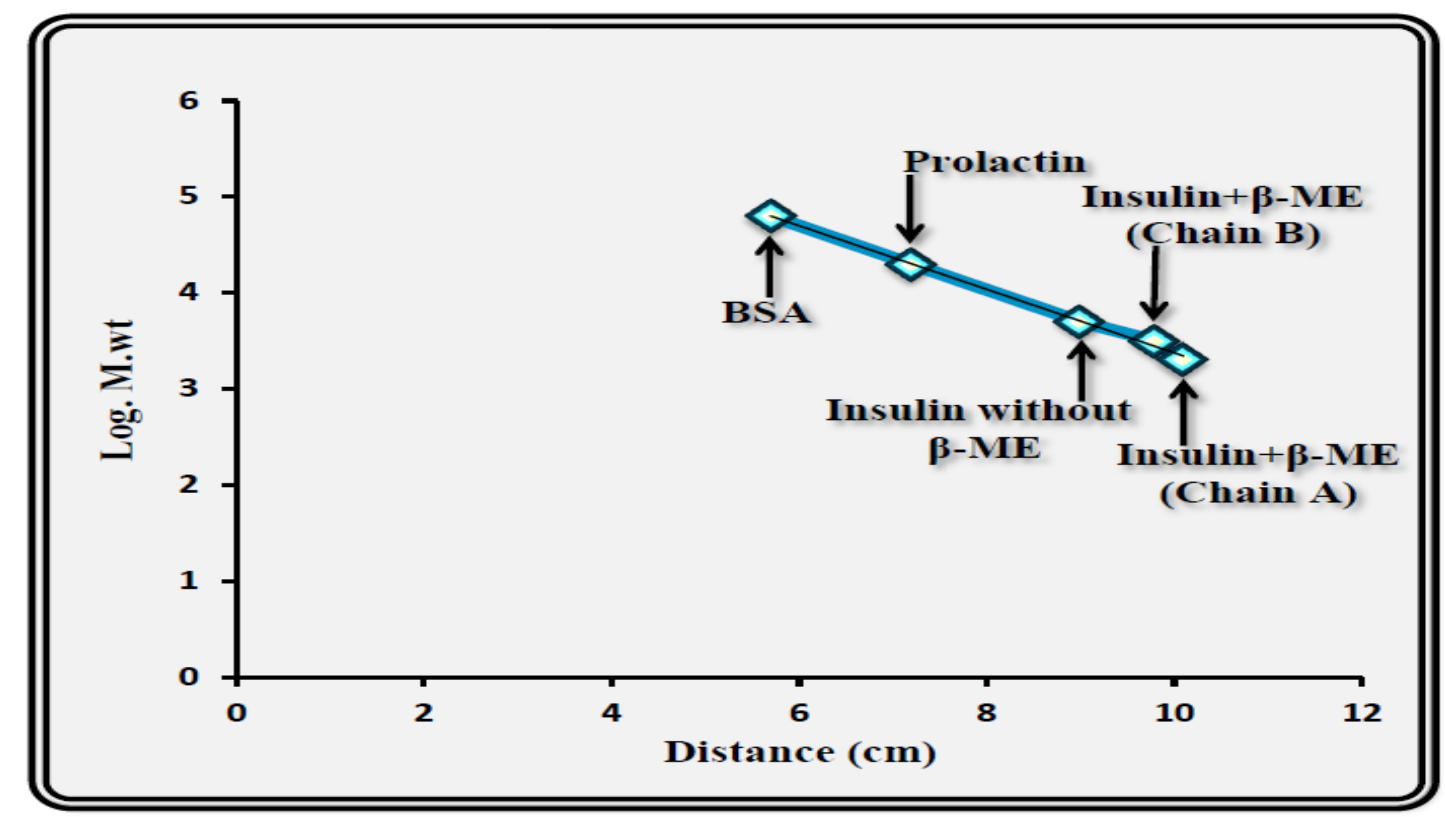

Fig. 8: Calibration curve for molecular weight estimation by SDS-Polyacrylamide gel electrophoresis using known molecular weight proteins.

\section{Connection of osteocalcin by glycogroups:}

The result show by Molisch's test that isolated osteocalcin (peak B) from human plasma and rats serum was glycoprotein, these results agree with those (Gladwin, 2017) who demonstrate that osteocalcin is glycoprotein.

\section{CONCLUSION}

It was concluded that using biochemical techniques for partial purification of osteocalcin from healthy human plasma and healthy rats serum was gave a good results, and higher purity of osteocalcin present in human.

\section{REFERENCES}

Allwsh, T.A.; Mohammad, J.A. (2013). Clinical study of obestatin hormone and its relation to diabetes mellitus. Raf. J. Sci. 24(4), 74-87.

Allwsh, T.A.; Mohammad, J.A. (2014). The effect of isolated obestatin hormone from plasma on some biochemical parameters in normal and diabetic rats. Raf. J. Sci. 25(1), 82-100.

Columbia news. (2007). Research shows skeleton to be endocrine organ. http://www.columbia.edu/cu.

Fattore, A.D.; Sobacchi, C.; Rauner, M.; Coudert, A. (2015). The Endocrine role of the skeleton. Internat. J. Endocrinol. 10, 1-2.

Ferron, M.; Lacombe, J. (2014). Regulation of energy metabolism by the skeleton: Osteocalcin and beyond. J. Archives of Biochemistry and Biophysics. 561,137-146.

Gladwin, R. (2017). Types of cartilage. http://www.rahulgladwin.com/noteblog/histology/types-of cartilage.php. 
Hauschka, P.V.; Lian, J.B.; Gallop, P.M. (1975). Direct identification of calcium-binding amino acid gamma-carboxyglutamate, in mineralized tissue. J. Proc. Natl. Acad. Sci. USA. 72(10), 3925-3929.

Hill, H.S.; Grams, J.; Walton, R.G.; Liu, J.; Moellering, D.R.; Garvey, W.T. (2014). Carboxylated and uncarboxylated forms of osteocalcin directly modulate the glucose transport system and inflammation in adipocytes. J. Horm. Metab. Res. 46, 341-347.

Hosoda, K.; Honda, H.; Kubota, T.; Masuho, Y. (1996). Method of immunological assaying of human osteocalcin, reagent and kit therefor, antibody to human osteocalcin, hybridoma producing said antibody, and method of producing it. J. U. S. Patent. 316, 1-24.

Ivaska, K. (2005). Osteocalcin: Novel insights into the use of osteocalcin as a determinant of bone metabolism. http://www.doria.fi/handle/10024/46615?locale+len\&author.

Kanazawa, I. (2015). Osteocalcin as a hormone regulating glucose metabolism. World $J$. Diabetes. 6(18), 1345-1354.

Laemmli, U.K. (1970). Cleavage of structural proteins during the assembly of the head of bacteriophage T4. J. Nature. 227:680-685.

Liu, J.M.; Rosen, C.J.; Ducy, P.; Kousteni, S.; Karsenty, G. (2016). Regulation of glucose handling by the skeleton: Insights from mouse and human studies. J. Diabetes. 65(11), 3225-3232.

Mizokami, A.; Yasukochi, K. T.; Hirata, M. (2017). Osteocalcin and its endocrine functions. J. Biochem. Pharmacol. 132, 1-8.

Nagasue, K.; Inaba, M.; Okuno, S.; Kitatani, K.; Imanishi, Y.; Ishimura, E.; Miki, T.; Kim, M.; Nishizawa, Y. (2003). Serum N-terminal midfragment vs. intact osteocalcin immunoradiometric assay as markers for bone turnover and bone loss in hemodialysis patients. J. Biomed. Pharmacother. 57(2), 98-104.

Nishimoto, S.K.; Waite, J.H.; Nishimoto, M.; Kriwacki, R.W. (2003). Structure, Activity, and distribution of fish osteocalcin. J. Biol. Chem. 278(14), 11843-11848.

Oldknow, K.J.; MacRae, V.E.; Farquharson, C. (2015). The endocrine role of bone: Recent and emerging perspectives beyond osteocalcin. J. Endocrinol. 14, 1-46.

Poser, J.W.; Esch, F.S.; Ling, N.C.; Price, P.A. (1980). Isolation and sequence of the vitamin Kdependent protein from human bone. J. Biol. Chem. 255(18), 8685-8691.

Price, P.A.; Nishimoto, S.K. (1980). Radioimmunoassay for the vitamin K-dependent protein of bone and its discovery in plasma . J. Proc. Natl. Acad. Sci. USA. 77, 2234-2238.

Price, P.A.; Otsuka, A.A.; Poser, J.W.; Kristaponis, J.; Raman, N. (1976). Characterization of gamma-carboxyglutamic acid-containing protein from bone. J. Proc. Natl. Acad. Sci. USA. 73(5), 1447-1451.

Robyt, F.J.; White, J.B. (1987). Biochemical Techniques Theory and Practice. Books Cole Publishing Co., U.S.A., 141, 235-236, 246, 263, 269.

Schacterle, G.R.; Pollack , R.L. (1973). A simplified method for the quantitatiue assay of small amounts of protein biological material. J. Anal. Biochem. 51, 654-655.

Viegas, C.S.B.; Pinto, J.P.; Conceicao, N.; Simes, D.C.; Cancela, M.L. (2002). Cloning and characterization of the cDNA and gene encoding Xenopuslaevis osteocalcin. J. Gene. 289, 97-107.

Zoch, M.L.; Clemens, T.L.; Riddle, R.C. (2016). New insights into the biology of osteocalcin. J. Bone and diabetes. 82, 42-49. 